\title{
What are social-ecological systems and social-ecological systems research?
}

\author{
Reinette Biggs, ${ }^{1,2}$ Hayley Clements, ${ }^{1}$ Alta de Vos, ${ }^{3}$ \\ Carl Folke, ${ }^{2}$ Amanda Manyani, ${ }^{1}$ Kristine Maciejewski, ${ }^{1}$ \\ Berta Martín-López, ${ }^{4}$ Rika Preiser, ${ }^{1}$ \\ Odirilwe Selomane ${ }^{1}$ and Maja Schlüter ${ }^{2}$ \\ ${ }^{1}$ CENTRE FOR SUSTAINABILITY TRANSITIONS, STELLENBOSCH UNIVERSITY, STELLENBOSCH, SOUTH AFRICA \\ ${ }^{2}$ STOCKHOLM RESILIENCE CENTRE, STOCKHOLM UNIVERSITY, STOCKHOLM, SWEDEN \\ ${ }^{3}$ DEPARTMENT OF ENVIRONMENTAL SCIENCE, RHODES UNIVERSITY, MAKHANDA, SOUTH AFRICA \\ ${ }^{4}$ SOCIAL-ECOLOGICAL SYSTEMS INSTITUTE, FACULTY OF SUSTAINABILITY, LEUPHANA UNIVERSITY, LÜNEBURG, GERMANY
}

\section{The Anthropocene: the challenge of understanding the world in new ways}

The period since the Second World War has been marked by rapid and accelerating changes to many aspects of human society and the environment (Clark, Crutzen, and Schellnhuber 2004; Steffen et al. 2011; Steffen et al. 2015a). There is accumulating evidence and rising concern about the potential consequences these changes hold for key Earth system processes at a global scale, and human well-being and prosperity into the future (Krausmann et al. 2013; Steffen et al. 2015b). The Anthropocene, as this new era of extensive human impact on the Earth has come to be known (Crutzen 2006), manifests in a closely intertwined set of social and ecological changes. Technological advances, increasing human population, rising levels of wealth and consumption, and the institutional arrangements we have developed to govern our economies and societies interplay with one another, and drastically affect the Earth's climate, biological diversity, freshwater and biogeochemical flows, and levels of novel pollutants in the environment (Steffen et al. 2015a). These environmental changes, in turn, contribute to increasingly frequent and severe droughts (Dai 2013; Trenberth et al. 2014), floods (Milly et al. 2002; Nicholls 2004), heatwaves (Guo et al. 2018; Oliver et al. 2018) and the emergence of novel pathogens such as SARSCoV-2 (Everard et al. 2020; O'Callaghan-Gordo and Antò 2020; Schmeller, Courchamp, and Killeen 2020) that can lead to massive societal disruption and hardship, especially among the poor (Wheeler and Von Braun 2013; Barbier and Hochard 2018).

The intertwined social and ecological changes that underlie the Anthropocene are further reflected in a world that has become highly connected through technology and trade (Green et al. 2019; Keys et al. 2019; Nyström et al. 2019). Nowadays, it is difficult to keep track of the geographic origin of our food, or to account for the various components making up the mobile 
phones we use every day. While this connectivity has brought about impressive improvements to many people in terms of the distribution of food and other resources around the world, it has also resulted in conglomerations of markets and resources, making it difficult to trace and hold accountable those polluting rivers and degrading ecosystems. Large and often geographically distant supply chains of resources have increased access to and human consumption of many goods, but simultaneously have had devastating consequences for biodiversity and species habitats, without consumers feeling accountable for or being aware of these impacts (Lenzen et al. 2012; Wilting et al. 2017; Liu et al. 2018). Vast and globally extensive supply chains have also contributed to widespread inequalities between and within countries (Costinot, Vogel, and Wang 2012; Galaz et al. 2018). This multi-dimensional connectivity also means that decisions in one country or part of the world can have far-reaching consequences for other places or countries - economically, socially and ecologically. Small-scale fishers, for example, are now often directly and indirectly connected to distant markets, causing them to be more vulnerable to seemingly unrelated threats and disturbances, such as economic changes in distant economies (Crona et al. 2015; Stoll et al. 2018). Similarly, the interdependence of countries in food supply reduces resilience and increases vulnerability as supply chains are broken (Kummu et al. 2020).

The pressing environmental and social sustainability challenges we face in the 21st century are clearly deeply intertwined. These challenges result from the confluence and interaction of multiple, mutually reinforcing social and ecological processes at multiple scales (Folke et al. 2016), where social processes include economic, political, cultural and technological processes, and ecological processes include biotic (e.g. population dynamics, food web interactions) and abiotic (e.g. nutrient flows, climate patterns) processes. The climate emergency and other environmental changes are underlain by a complex, interacting array of social changes, which themselves are shaped by the environment and environmental disruptions. Similarly, problems of poverty and inequality are often linked to and exacerbated by environmental change and disruption. Ethiopia, for example, has become one of the most food-insecure nations in the world due to complex interactions between environmental degradation, diminishing land holdings, outbreaks of crop and livestock disease, poor infrastructure, political insecurity, and pre- and post-harvest crop losses that have systematically eroded the productive assets of households (Mohamed 2017; Bahru et al. 2019). Factors outside a country also play a role in perpetuating food insecurity in that country, such as discourses about how to address these problems driven by notions of intensification, commercialisation (Jiren et al. 2020) and land acquisition by other countries for their own benefit (e.g. Hules and Singh 2017). The key sustainability challenges of the 21st century cannot be addressed without recognising the systemic, intertwined nature of these problems (Liu et al. 2015).

The recognition that environmental and social sustainability challenges are inherently systemic and intertwined, and the escalating urgency to address these challenges, have driven a paradigm shift in how social and natural systems are studied (Schoon and Van der Leeuw 2015). In most scientific disciplines, humans and nature have been treated as separate entities (Folke et al. 2016). Ecology, for example, has often viewed social systems only as external drivers of ecosystem dynamics (Carpenter et al. 2012; Cumming 2014), whereas economics and other social sciences have considered natural systems simply as resources for extracting capital gains or providing a basis for livelihoods (Gunderson and Holling 2002; Berkes, Colding, and Folke 2003). In recent decades, however, this thinking has been widely contested and is changing, partly influenced by the rise in systems sciences and complexity thinking (see Chapter 2; Preiser et al. 2018). Scholars in different disciplines are increasingly viewing human systems as interdependent, inseparable and intertwined with ecosystems, embedded within and dependent upon the biosphere and the broader Earth system (Folke et al. 2016; Reyers et al. 2018; Schlüter et al. 
2019). Furthermore, there is growing recognition of the need for knowledge production processes that account for and engage with the complex interconnections and interplay between the social and the ecological, and the emergent and often unexpected processes, features, problems and opportunities to which they give rise (Preiser et al. 2018).

\section{What are social-ecological systems?}

'Social-ecological systems' (SES) is an emerging concept for understanding the intertwined nature of human and natural systems in this new, interconnected and interdependent way. The SES concept developed in the early to mid-1990s through collaboration of scholars working in the interdisciplinary areas of ecological economics and common-pool resource systems (e.g. Berkes 1989; Ostrom 1990; Costanza 1991). Specifically, the volume Linking Social and Ecological Systems: Management Practices and Social Mechanisms for Building Resilience combined a systems approach and adaptive management with a focus on dynamic institutions and diverse systems of property rights, with 14 case studies analysing ecological resilience and local and traditional systems engaged in ecosystem management (Berkes and Folke 1998). The concept of SES is based on the notion that 'the delineation between social and natural systems is artificial and arbitrary' (Berkes and Folke 1998), emphasising that people and nature are intertwined. Nature no longer merely sets the space in which social interactions take place; likewise, people are not just an external driver in ecosystem dynamics (Folke et al. 2011; Schoon and Van der Leeuw 2015). Social-ecological systems are therefore not merely social plus ecological systems, but cohesive, integrated systems characterised by strong connections and feedbacks within and between social and ecological components that determine their overall dynamics (Folke et al. 2010; Biggs, Schlüter, and Schoon 2015).

As such, SES are a type of complex adaptive system. These systems comprise many interdependent parts that interact in ways that give rise to emergent, system-wide patterns that cannot be predicted from the properties of the individual system components. Furthermore, these system-wide patterns, in turn, influence the behaviour of the individual system parts and their interactions with other parts, creating a feedback process that shapes the evolution of the system over time and allows it to adapt to changing contexts (Lansing 2003). The continuous interplay between microlevel entities to form emergent macrolevel patterns 'implies that SES are more than the sum of the ecological or the social parts' (Reyers et al. 2018). Furthermore, it means that SES can adapt to changing conditions, learning and self-organising in response to internal or external pressure (Levin et al. 2013). An example of these dynamics is the emergence of adaptive governance, where individuals interact and collaborate, often in response to a crisis, connecting and creating social networks around shared visions and narratives (Folke et al. 2005). As a result, bridging organisations and new institutions emerge and become connected to other levels of governance, influencing them, but also being influenced by them. It has been shown that an entire SES may shift and start to evolve new pathways as a result of this interplay. Examples range from landscape management in Sweden, to large-scale coral reef management in Australia, to a system of global adaptive governance of the regional resources of the Southern Ocean (Schultz et al. 2015).

A recent review by Preiser et al. (2018) identifies six organising principles of complex adaptive systems that help to further inform our understanding of the nature of SES. The first is that such systems are constituted relationally, i.e. the relations and interactions between the components of the system are more important to understanding the properties and behaviour of an SES than the properties of the individual components of the system themselves. This recognition highlights the need to shift from a traditional reductionist scientific approach, which aims to understand a system by breaking it down into its component parts, to a systems-based approach that focuses on system interactions rather than system components (see Chapter 2). 
The second principle is that SES have adaptive capacities. The many interrelations in the system create feedback processes that enable an SES to continuously adjust and adapt to changing conditions, brought about either by the system itself or by external forces. Through this process of adaptive change, unique trajectories of development emerge that contain specific historical legacies. These legacies and 'memories', in turn, constrain and shape future development options and possibilities.

The third critical feature of SES is that the dynamic interactions within the system are often non-linear, meaning that small changes can lead to large and surprising effects, or vice versa (Levin et al. 2013). This behaviour is caused by feedback loops that either dampen or amplify system changes and perturbations, and can trigger regime shifts - large, persistent, and often sudden and unexpected reorganisation in the structure and functioning of an SES, such as soil salinisation, ice-sheet collapse or a shift from collaborative institutions to regulate use of common-pool resources to overharvesting (Scheffer et al. 2001; Lade et al. 2013; Biggs, Peterson, and Rocha 2018). Changes leading to regime shifts, and different regime shifts themselves, are often connected across scales, and can lead to cascading regime shifts at different scales (Rocha et al. 2018). Similar non-linear processes underlie transformations - intentional actions that aim to trigger fundamental reorganisation of an SES to create more sustainable and equitable outcomes (Olsson, Galaz, and Boonstra 2014). Enabling such transitions usually involves working at multiple scales to weaken dominant relationships and structures in a system, while at the same time developing new 'shadow' networks and processes that can take their place when a crisis or opportunity for change emerges (Olsson et al. 2006; Pereira et al. 2018).

The fourth feature is that SES do not have clear boundaries. Due to extensive interactions and connections between an SES and its broader environment, it is very difficult to discern which components belong inside the system and which belong to the broader environment. Deciding on system boundaries therefore often depends on the purpose of the study and the perspective of the observer (Cilliers 2001). Linked to this is the fifth feature, namely that SES are context dependent. As the context changes, the system will change and elements in the system may take on a different role or function. Many SES, for example, have through learning and experience developed strategies and institutions that are dormant but that can easily be revived when the context changes, such as in situations of resource scarcity or shocks and stresses (Berkes and Folke 1998).

Finally, SES are characterised by complex causality and emergence. Cause and effect in SES are not unidirectional or linear, but are marked by complex recursive causal pathways. Social-ecological systems therefore cannot be understood nor can their behaviour be predicted based solely on information relating to their individual parts. Many emergent system properties are inherently unpredictable as they involve non-linear effects, learning, evolution, novelty and innovation. Although SES can be influenced, and aspects of these systems can be understood and navigated, these features make prediction and control of SES very difficult, if not impossible.

The recognition that social and ecological systems are inseparable, and function as intertwined complex adaptive systems, offers researchers, policymakers and scholars an alternative entry or viewpoint for studying and engaging with the complex challenges that arise from human-nature interactions (Binder et al. 2013; Preiser et al. 2018; Reyers et al. 2018). In particular, it shifts the focus to understanding how macrolevel system properties emerge from the interactions of microlevel entities and their external environment, rather than separating social and ecological components and studying them in isolation (Levin et al. 2013; Preiser et al. 2018). It also emphasises the dynamic interplay of rapid and gradual change (fast and slow variables), and the critical importance of multi- and cross-scale interactions across space and time in forging different pathways of change and options for the future (Gunderson and Holling 2002; Adger, Arnell and Tompkins 2005; Cash et al. 2006). Finally, the properties 
of complex adaptive systems emphasise the need to expect and embrace surprise and uncertainty, to be reflexive and acknowledge the limits of what is knowable or controllable in SES. Chapter 2 discusses the properties of complex adaptive systems and their implications for SES research in further detail.

\section{What is SES research?}

Understanding SES as complex adaptive systems has profoundly shaped the development of SES research (Levin et al. 2013; Schoon and Van der Leeuw 2015; Preiser et al. 2018; Hertz, Mancilla García, and Schlüter 2020; Mancilla García et al. 2020). Early work on SES (Berkes and Folke 1998) was inspired by insights on people-nature interdependence from anthropology, ecology and geography, among others (e.g. Holling 1973; Bateson 1979; Clark and Munn 1986; Odum 1989; Gunderson, Holling, and Light 1995; Levin 1999; Davidson-Hunt and Berkes 2003). Since the concept of SES was translated into a framework for researching intertwined systems of people and nature (Berkes and Folke 1998), over 13000 papers have been published on SES, predominantly drawing on the environmental and social sciences, economics and, to a lesser extent, medicine, psychology, and the arts and humanities (Colding and Barthel 2019). Social-ecological systems research now represents a recognised interdisciplinary area (e.g. Ostrom 2009; Colding and Barthel 2019) of sustainability science (Clark and Harley 2020). In several dimensions, it is similar to and overlaps with other people-nature approaches like human-environment systems covering land-system change, vulnerability or environmental literacy (e.g. Turner et al. 1990; Lambin et al. 2001; Turner, Lambin, and Reenberg 2007; Lambin and Meyfroidt 2011; Scholz 2011); coupled human and natural systems (CHANS) and the telecoupling framework (Liu et al. 2007b, 2013); or socio-natural systems that emerged from archaeology (Van der Leeuw 2019). However, a distinguishing feature of the SES approach is its conceptual emphasis on SES as complex adaptive systems (Folke et al. 2016), although the extent to which this is operationalised in empirical research varies.

Social-ecological systems research is largely problem-oriented, with a strong focus on informing sustainability policy and practice (Fischer et al. 2015; Folke et al. 2016), playing a particularly significant part in the development of resilience and adaptive governance approaches (e.g. Gunderson and Holling 2002; Berkes, Colding, and Folke 2003; Dietz, Ostrom, and Stern 2003; Folke et al. 2005; Walker and Salt 2006; Biggs, Schlüter, and Schoon 2015). Notable increases in SES research occurred following calls to move towards 'sustainable development of the Biosphere', and to integrate SES within broader sustainability initiatives, such as the Sustainable Development Goals and Future Earth (Herrero-Jáuregui et al. 2018; De Vos, Biggs, and Preiser 2019). Recent reviews find SES research to be focused on pressing sustainability issues such as climate change, biodiversity loss, livelihoods, poverty, policy, landuse change, water, and social and environmental justice (Herrero-Jáuregui et al. 2018; De Vos, Biggs, and Preiser 2019), and frequently used terms in SES publications include 'policy', 'trade', 'conservation', 'adaptation', 'land-use change', 'water', 'forest loss', 'sustainability', 'urban', 'governance' and 'institutions' (De Vos, Biggs, and Preiser 2019). An analysis of the semantic networks resulting from SES research shows that terms such as 'solution' and 'transformation' are placed towards the centre of the network, being essential to connecting different types of studies (Horcea-Milcu et al. 2020). Baggio, Brown and Hellebrandt (2015), in their citation network analysis of resilience, a concept often closely linked to that of SES, found that

the social-ecological systems field stands out as an emerging interdisciplinary arena where resilience can effectively act as a bridging concept and facilitate a discussion of 
dynamics of complex systems within varied contexts, informed by diverse perspectives, to provide potentially innovative theoretical and applied insights.

Early SES research consisted largely of place-based studies of local resource management (Ostrom 1990; Folke and Berkes 1998). Twenty years on, SES research is still often focused on local-scale studies (Norberg and Cumming 2008; Colding and Barthel 2019; De Vos, Biggs, and Preiser 2019), although network approaches and approaches that capture crossscale dynamics connecting local, regional and global processes are becoming more common (Galaz et al. 2011; Österblom and Folke 2013; Crona et al. 2015; Cumming et al. 2015; Bodin 2017; Rocha et al. 2018; Selomane et al. 2019). There is also an increasing emphasis on the need for coordination and integration between case studies to enable comparison, synthesis and theory development in SES (Ostrom 2009; Cox 2014; Gurney et al. 2019; Cumming et al. 2020). Several large databases now exist to collect case studies for meta-analyses (Cox 2014; Biggs, Peterson, and Rocha 2018; Partelow 2018), and meta-analysis and large- or crossscale SES research are increasingly being undertaken (e.g. Cox, Arnold, and VillamayorTomas 2010; Hamann, Biggs, and Reyers 2015; Cinner et al. 2016; Ban et al. 2019).

While a focus on the interactions between people and nature is at the core of SES research, the degree to which the 'social' and the 'ecological' are researched as part of a single integrated system varies among studies (Schlüter et al. 2019). Much SES research is still focused either more on the social or more on the ecological elements (Binder et al. 2013; Epstein et al. 2013; Schlüter et al. 2019), and still often investigates one-way links between social and ecological elements, such as the human drivers of ecosystem dynamics or the benefits nature provides to people (Binder et al. 2013; Schlüter et al. 2019). There is a growing recognition, however, that people and nature are interdependent and coevolving, through multiple interactions or feedbacks. Ecosystem services, for example, are increasingly seen as co-produced by both people and nature (Reyers et al. 2013; Palomo et al. 2016); human behaviour and individual and social identities are increasingly understood as relationally constructed and coevolving with the biophysical context (Díaz et al. 2015; Chan et al. 2016; Schill et al. 2019); and the interactions between human well-being or inequality and ecosystems are increasingly recognised as dynamic and reciprocal (Hamann et al. 2018; Masterson et al. 2019). Consequently, research is shifting from focusing on social and ecological elements, to social-ecological relations as the key to SES dynamics (Schlïter et al. 2019; Hertz, Mancilla García, and Schlüter 2020; Mancilla García et al. 2020). Efforts to better capture the dynamic nature of SES have led to an evolution of the original notion of linking social and ecological systems (Berkes and Folke 1998), to research on the 'intertwined' nature of SES (Folke et al. 2016; Schlüter et al. 2019). These changes are evident in the steady increase of articles studying SES as complex adaptive systems (Liu et al. 2007a; Levin et al. 2013), and frameworks for understanding SES (Binder et al. 2013; Schlüter et al. 2019).

The interdisciplinary nature of SES research, its growing need to go beyond the 'sum' of social and ecological research, and the need to focus on cross-scale systemic dynamics have resulted in a high degree of methodological pluralism (De Vos, Biggs, and Preiser 2019). Many methods and approaches used in SES research go beyond traditional social and natural sciences, or any single discipline (Tengö et al. 2014; Folke et al. 2016; De Vos, Biggs, and Preiser 2019). Social-ecological systems research often requires adapting methods, or implementing a sequence of methods, such that they capture both the social and the ecological domains, and their dynamic interdependencies (Fischer et al. 2015; De Vos, Biggs, and Preiser 2019). This has given rise to a variety of models, policies and methods for the practical application of SES research (Rogers et al. 2013; Preiser et al. 2018; Reyers et al. 2018). 
Furthermore, given the problem-oriented nature of SES research, there is growing recognition that the application of SES research to policy and practice requires collaborations between researchers and practitioners holding multiple types of knowledge, an approach known as transdisciplinarity (Mauser et al. 2013; Roux et al. 2017).

As a consequence of its inter- and transdisciplinary nature, SES research is predominantly conducted in teams. Student projects are often embedded within larger research projects, which typically involve multiple SES researchers, often with different disciplinary backgrounds (Kelly et al. 2019). Social-ecological systems project teams may also often involve practitioners and various stakeholders relevant to the particular research. This context means that SES research tends to be highly collaborative, requiring particular skills and approaches, as further discussed in Chapter 3. In particular, various knowledge co-production and participatory approaches increasingly characterise transdisciplinary SES research (Gurney et al. 2019) and highlight the need for agile collaboration between SES research and practice, and the development of stronger science-society interfaces to guide research, knowledge co-creation and decision-making (Tengö et al. 2014; Fischer et al. 2015; Reyers et al. 2018).

\section{SES frameworks}

All research fields are implicitly or explicitly based on certain conceptions about the nature of the world that they study. Social-ecological systems research as discussed above and throughout this book is motivated by the desire to address pressing sustainability issues facing society, and is framed by an approach grounded in an understanding of SES as complex adaptive systems, where people and nature are intertwined and coevolve (Figure 1.1) (also see Chapter 2). This broad framing underlies different areas of SES research, such as adaptive governance, resilience assessment and transformations towards sustainability. Within these research areas, SES researchers often use one or more frameworks that specify a particular way of conceptualising SES and guide researchers towards the elements, relations and processes of an SES that are considered relevant for a given problem or research question. Ostrom's SES framework (Ostrom 2007), for instance, is a key framework used in the study of common-pool resource management. The different research areas and their frameworks, and the research questions associated with them, in turn, inform the use of particular methods from the diverse array of methods employed in SES research (also see Chapter 3 for further discussion).

Frameworks play a particularly important role in SES research. The SES field does not build on a set of well-established 'laws' or theories that are tested in particular cases; instead, studies are largely guided by the overarching SES approach and various frameworks linked to particular areas of SES research.

Frameworks used in SES research draw on a diverse set of perspectives and theoretical commitments, often originating in a variety of different disciplines. The main purpose of these frameworks is to identify, categorise and organise those factors deemed most relevant to understanding a particular phenomenon (McGinnis 2011). Frameworks aim to guide an investigation or activity by pointing to the concepts, elements, variables, links or processes of an SES that are characteristic or critical, or that help explain or predict particular SES outcomes (e.g. institutional arrangements that facilitate governance for sustainability) or that help affect system change.

Beyond this generic aim, however, purposes and forms of frameworks vary widely. These range from descriptive (conceptual frameworks), to analytical/explanatory (analytical 


\section{SUSTAINABILITY CHALLENGES}

\section{SES APPROACH}

\section{Complex adaptive systems view}

An understanding of systems that emphasises their interconnected and adaptive, evolving nature

Social-ecological intertwinedness

A view of human-environment services that emphasises the interdependence between people and nature and their coevolution

\section{SES research areas}

A subfield of SES research that focuses on particular issues, processes or aspects of SES, e.g. adaptive governance, resilience assessment, ecosystem services

may be associated with particular

\section{Methods}

The way a system is studied

\section{Frameworks}

A collection of concepts or a conceptual model that indicates what system elements and relationships are important for a research project

Figure 1.1 The SES approach discussed in this book is grounded in an understanding of SES as intertwined, complex adaptive systems embedded in the biosphere. This understanding directly informs the frameworks and methods employed in different areas of SES research. (@ Reinette Biggs)

frameworks), to serving as boundary objects for interdisciplinary collaboration or heuristics for problem solving. In inter- and transdisciplinary processes, frameworks can help bring together insights from different disciplines or highlight incompatibilities between different worldviews. When used as a tool to facilitate collaboration, the process of developing the framework is as important as or even more important than the framework itself. Identifying the elements of the framework and the links between them helps make explicit the assumptions and views of participants about what constitutes the system and how to study it. This increases mutual understanding and helps to develop a shared vocabulary for the study of the problem of interest. It can also facilitate narrowing down an investigation or activity into a feasible endeavour.

Some of the most common frameworks currently in use to study and analyse SES include: the original conceptual framework of linked SES developed by Folke and Berkes (1998) (Figure 1.2); the Panarchy framework depicting system resilience as an outcome of 


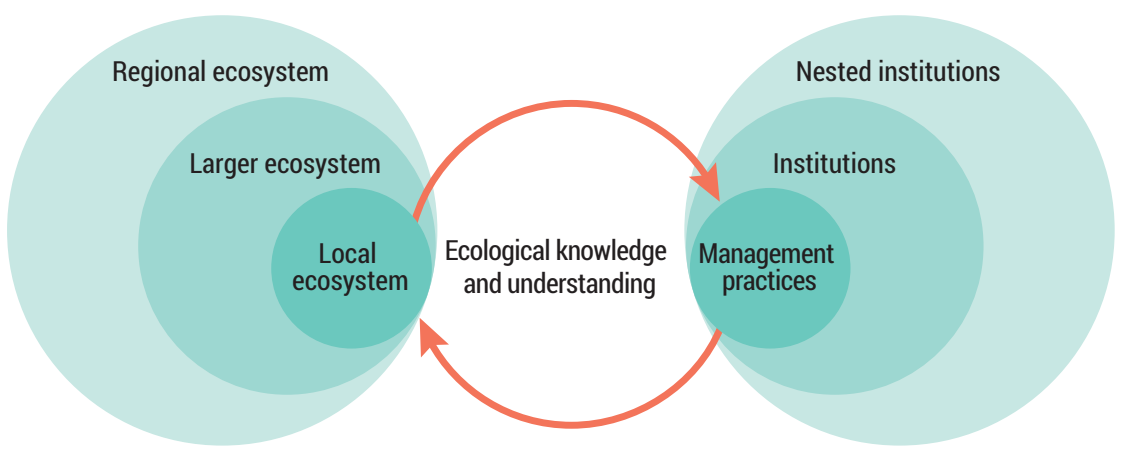

Figure 1.2 Linked SES framework (Folke et al. 2002)

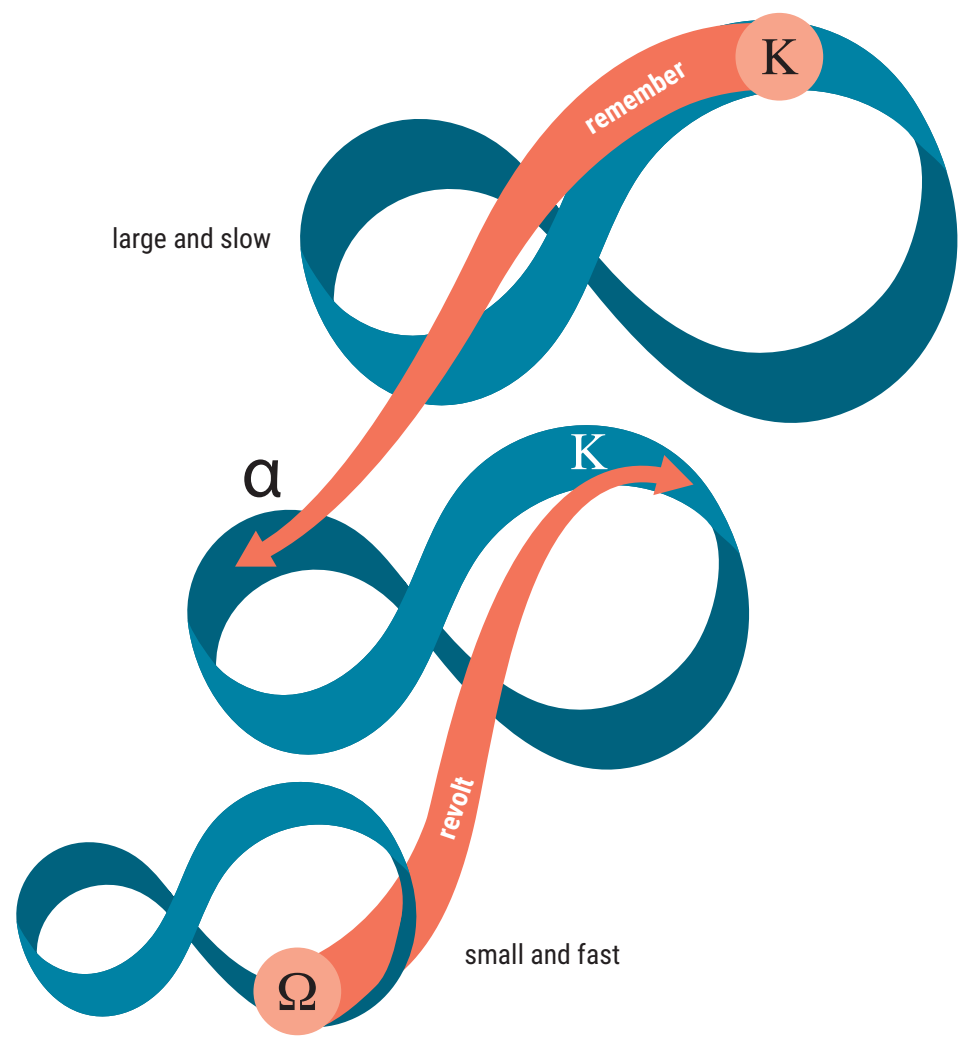

Figure 1.3 The Panarchy framework (Gunderson and Holling 2002)

connected adaptive cycles at different scales (Gunderson and Holling 2002) (Figure 1.3); the telecoupling framework that builds on the CHANS framework, developed by Liu, Yang and Li (2016) (Figure 1.4); the diagnostic framework developed by Ostrom (2007, 2009) to analyse common-pool resource systems (Figure 1.5); the diagnostic framework developed by Anderies, Janssen and Ostrom (2004) to analyse the robustness of SES using institutional analysis (Figure 1.6); and the social-ecological action situation (SE-AS) framework developed 
Sending system

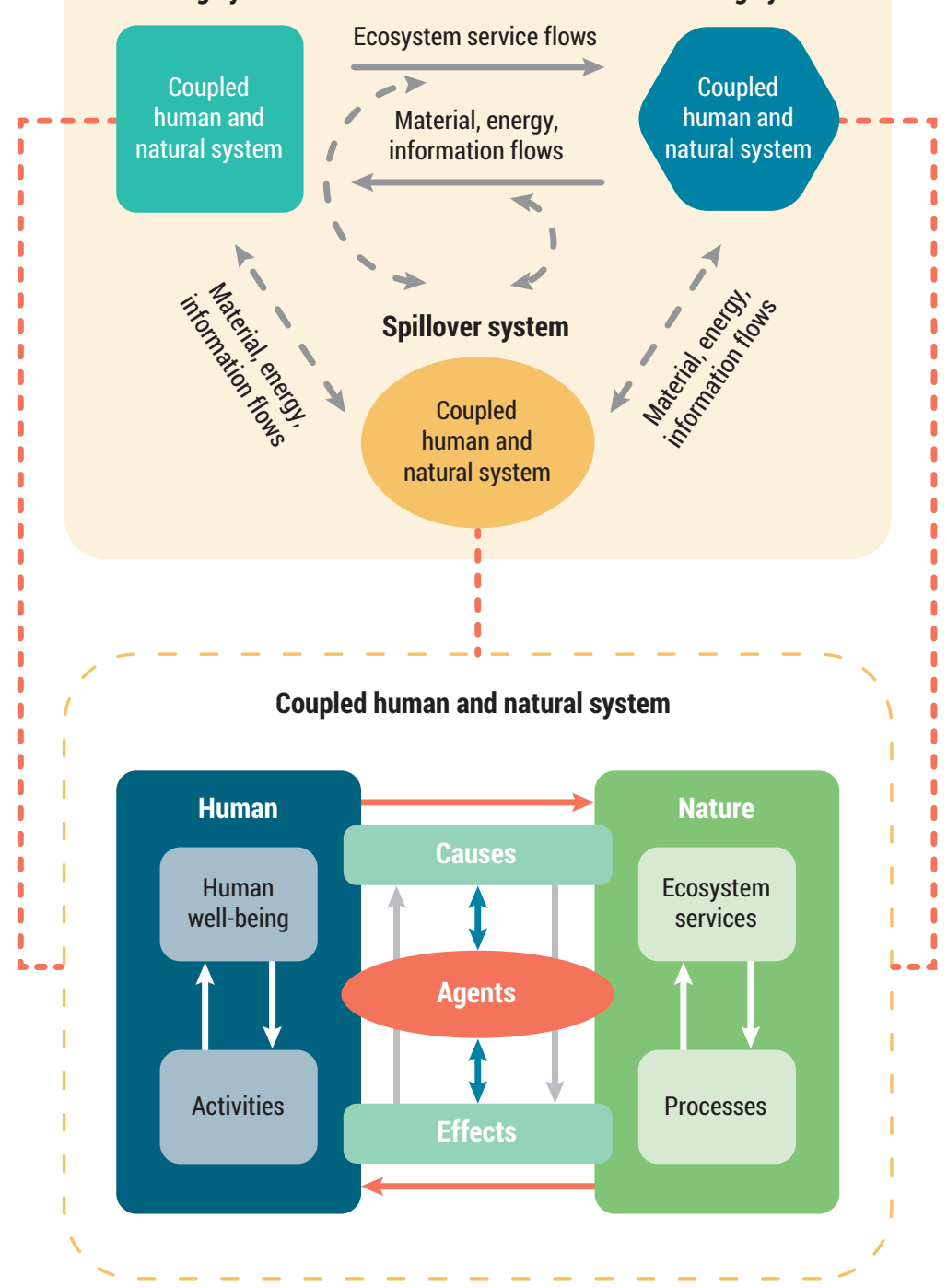

Figure 1.4 The telecoupling framework (Liu, Yang, and Li 2016)

by Schlüter et al. (2019) to analyse the emergence of social-ecological phenomena from social-ecological interactions (Figure 1.7).

The original SES framework (Berkes and Folke 1998) (Figure 1.2) is a conceptual framework that aims to inform the study of local resource management practices and outcomes, and emphasises the links between social and ecological systems and their multi-scale nature. It highlights relations on a highly abstract level, such as the embeddedness of management practices in nested institutions and the links between this multi-level social system and nested ecosystems at different scales. The connection between ecological and institutional systems relies on the ecological knowledge held by local users. The framework focuses on local 


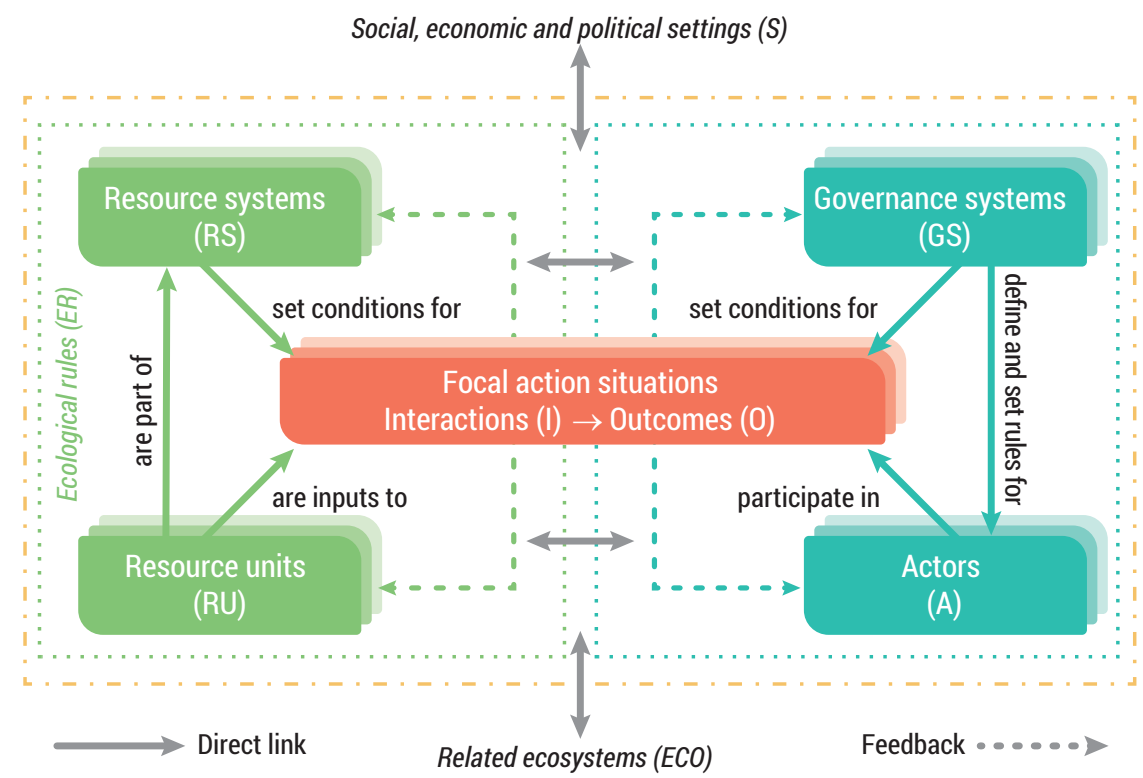

Figure 1.5 Ostrom's SES framework (Ostrom 2007, 2009)



Figure 1.6 The robustness framework (Anderies, Janssen, and Ostrom 2004)

management systems that are able to maintain institutional and ecological resilience in local settings, rather than systems dominated by top-down, conventional, command-and-control resource management (Colding and Barthel 2019). The framework continues to guide conceptual thinking, and is also used in combination with other frameworks such as those focusing on characteristics of resilience (e.g. Galappaththi et al. 2019). 


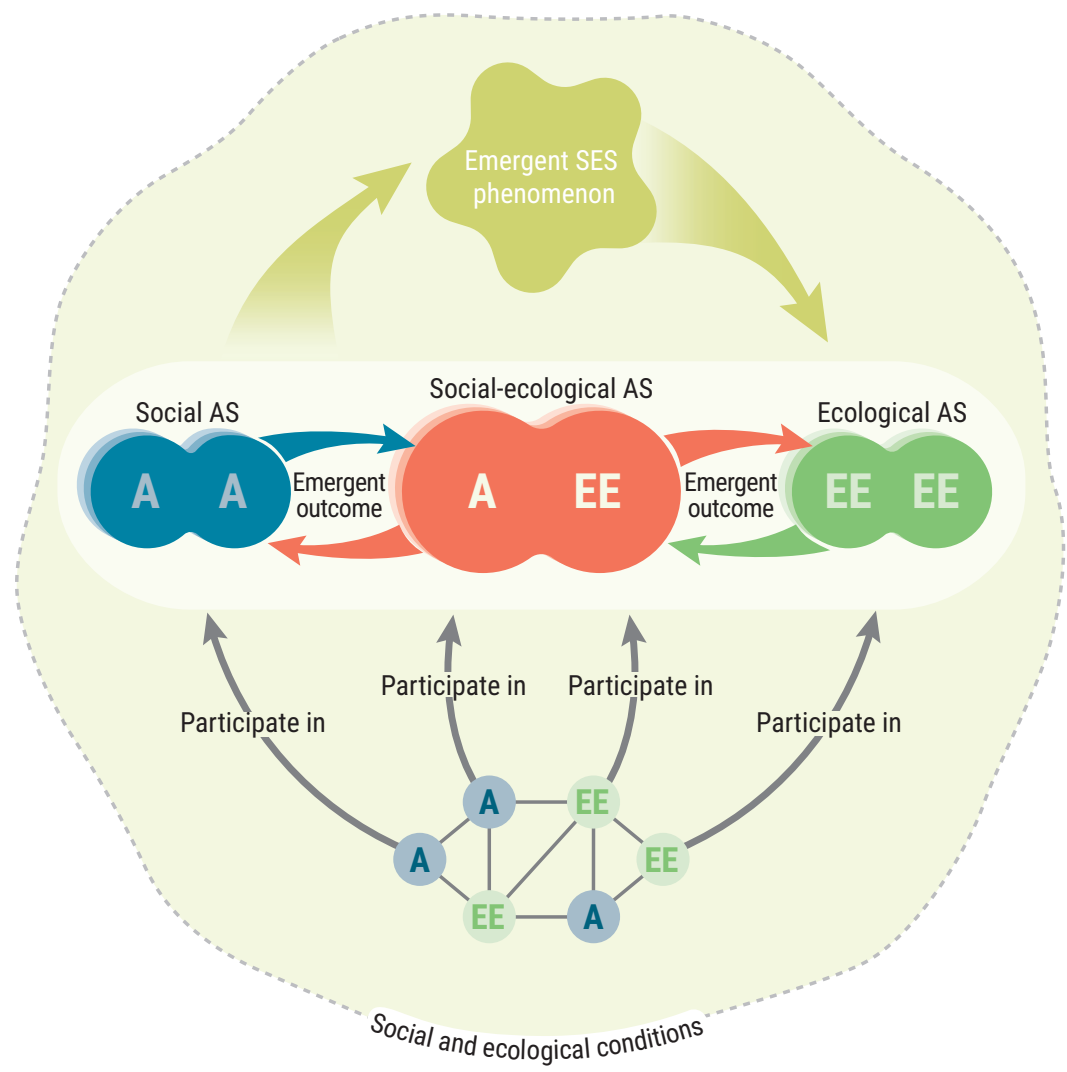

Figure 1.7 The social-ecological action situation (SE-AS) framework (Schlüter et al. 2019) (A: individual and collective actors; EE: ecological elements)

The Panarchy framework (Figure 1.3) explains system resilience as a function of adaptation and change over time, emphasising how changes in a system at one level are affected by the larger-scale systems within which they are embedded, and the smaller-scale systems embedded within them (Gunderson and Holling 2002). The framework is based on a looped 'adaptive cycle' that comprises four stages of change: growth, conservation (consolidation of connections), collapse (creative destruction) and reorganisation (Gunderson and Holling 2002). Panarchy consists of multiple interlinked adaptive cycles at different scales. At each scale, the adaptive cycle operates at different speeds. Larger-scale systems tend to have large, slow cycles that set the conditions for smaller, faster cycles of systems at smaller scales (e.g. in an ecosystem, the interactions between plants and animals, and the species that live there, are determined by climatic conditions and evolution). The faster levels tend to invent, experiment and test, whereas the slower levels stabilise, accumulating knowledge of the past (Folke 2006). In this way, systems develop and adapt to new conditions via a process of creating, testing and maintaining opportunity at one scale, buffered from collapse and regime shifts by the 'slower' processes of change at larger scales (e.g. seedbanks and evolved relationships, reorganised after each disturbance). In recent years, the framework has been used, among other applications, to understand small-island nation recovery and response to extreme weather events (Holdschlag and Ratter 2016), the interplay between legal systems, ecological 
resilience and adaptive governance in rapidly changing regional water systems (Gunderson et al. 2017; Cosens, Gunderson, and Chaffin 2018), how cross-scale connections can have an impact on social-ecological community resilience (Berkes and Ross 2016) and the spread of the Plague in Europe in the 14th century (Geobey and McGowan 2019).

The 'coupled human and natural systems' (CHANS) framework (Liu et al. 2007a) has a similar descriptive purpose to the Berkes and Folke (1998) framework, although it does not have a standard graphical depiction. Rather, the CHANS framework is associated with several different depictions highlighting that people and nature interact reciprocally across multiple spatial, temporal and organisational scales. The CHANS framework explicitly recognises the relevance of feedbacks, non-linearities, thresholds, time lags, legacy effects, path dependence and emergent properties in shaping human-nature interactions (Liu et al. 2007a).

The telecoupling framework (Figure 1.4) builds on the CHANS framework to incorporate flows of finances, information, energy, goods, organisms and other flows in an integrated way, often between two SES (Hull and Liu 2018) and is evolving to include a third SES, referred to as the 'spillover system' (Liu et al. 2018). The framework's recent applications include uncovering impacts of the following: trade (Friis and Nielsen 2017), telecoupled connections on smallholder farmers (Zimmerer, Lambin, and Vanek 2018), soy demands from China on Amazon forest degradation (Sun, Tong, and Liu 2017), biodiversity conservation (Carrasco et al. 2017) and many others.

Ostrom's SES framework (Ostrom 2007) (Figure 1.5) was developed as an explanatory framework for diagnosing common-pool resource management problems from an institutional and resilience perspective. It is based on the institutional analysis and development (IAD) framework (Ostrom 1990) and 30 years of empirical research on the ability of communities to manage their natural resources sustainably without top-down government regulation. The framework is a collection of social and ecological variables that have proven to be relevant for explaining or predicting when resource users can successfully self-organise to sustainably manage their common-pool resources. Its main unit of analysis is the action situation, which is a social interaction context where resource users interact with one another to produce outcomes (interactions and outcomes) enabled and constrained by rules, ecological settings and attributes of the community. The variables in the framework are organised in four high-level tiers: the resource system, the resource, the users and the governance system. Variables in each tier can be further specified into lower tiers, increasing the specificity of an analysis but at the same time making comparison more difficult. The framework serves two main aims: (a) to guide empirical data collection and analysis by pointing the analyst to those SES variables that may be important for explaining self-organisation and collective action, and (b) to provide a shared vocabulary (i.e. variables) to facilitate cross-case comparisons and support interdisciplinary collaboration. The SESMAD project (sesmad.dartmouth. edu) has collected and defined a list of the most common second- and third-tier variables. This framework has been applied extensively for place-based empirical studies, particularly in marine systems, fisheries, forestry and irrigation (see Partelow 2018 for a review of SES framework applications). While most applications focus on single case studies, there are also several recent studies that use the SES framework for case comparison or meta-analyses (e.g. Gutiérrez, Hilborn, and Defeo 2011; Villamayor-Tomas et al. 2020).

The robustness framework by Anderies and colleagues (2004) (Figure 1.6) is another analytical framework grounded in institutional analysis and the work of Elinor Ostrom. It aims to support the analysis and prediction of the robustness of SES to disturbances, where robustness is defined as the maintenance of system performance when subjected to unpredictable perturbations (Anderies, Janssen, and Ostrom 2004). It focuses on the institutional 
arrangements that shape the interactions among resource users, resources, public infrastructure providers and public infrastructure. Changes to the links between these critical SES components will affect the robustness of the SES. A disruption in the link between resource users and infrastructure providers, for instance, may critically affect the ability of the SES to respond to disturbance. The framework can help address questions such as how a given institutional arrangement affects the robustness of an SES, or why some SES persist in highly variable environments while others collapse. Recent applications of the framework include analyses of coastal system adaptation to global change (Anderies, Barreteau, and Brady 2019; Naylor et al. 2019) and identifying opportunities for ecosystem-based adaptation (Guerbois et al. 2019).

The social-ecological action situation (SE-AS) framework (Figure 1.7) is a recent development that further develops Ostrom's concept of an action situation to emphasise social-ecological interactions and how they give rise to emergent phenomena such as regime shifts or sustainable ecosystem management (Schlüter et al. 2019). The aim of this analytical framework is to support the development of hypotheses about the intertwined social and ecological processes that may have led to the emergence of particular phenomena. To this end, it introduces two other types of action situations in addition to the social action situations identified by Ostrom (2007): (a) the social-ecological action situations as situations in which humans and non-human elements of an SES (e.g. species, ecosystems, landscapes) interact, and (b) ecological action situations as situations in which ecological or biophysical elements interact (e.g. predation, parasitism, mutualism). A social-ecological phenomenon emerges from interactions of multiple action situations, which influence one another through their emergent outcomes. The collapse of the Baltic cod fishery, for instance, may be explained through the interactions of fishers with cod in fishing action situations, which are influenced not only by the interactions of cod with sprat but also by interactions within the governance system that introduced subsidies. One action situation can influence another, for instance by shaping its rules or changing the attributes of its participants. A possible explanation is thus represented as a configuration or network of action situations that are hypothesised to jointly give rise to a phenomenon, and can be further explored through fieldwork or agent-based modelling. First applications of the framework include supporting the development of global biodiversity targets that capture the interdependencies between biodiversity, ecosystem services and sustainable development (Reyers and Selig 2020), and identifying mechanisms of policy change during transformations to fisheries co-management (Orach and Schlüter, n.d.).

In addition to these SES frameworks, other SES research areas such as ecosystem services and vulnerability are partly undertaken within an SES approach, but substantial areas of work on these topics are also undertaken within other disciplines and approaches. Research on ecosystem services, for example, includes frameworks that span a range from more mechanistic and linear thinking (e.g. the cascade model: Potschin and Haines-Young 2011) to recognising complex dynamics and feedback loops across spatial and temporal scales (e.g. IPBES framework: Díaz et al. 2015). Some of this work such as the concept of 'nature's contributions to people' (Díaz et al. 2018) draws strongly on the SES approach in many respects, while other ecosystem services work is more closely aligned with conventional environmental economics approaches.

\section{Links between research and action}

Much SES research is problem focused, and the lines between research and action are often blurred. The goals of SES research are frequently to produce 'usable' knowledge, and often 
involve liaising or coordinating with policymakers and agencies to promote the integration of scientific knowledge and evidence into policy processes (Turner et al. 2016). Socialecological systems researchers frequently engage with multiple stakeholders and knowledge types in the course of their research (Lang et al. 2012), and typically produce a broader set of outputs and outcomes than conventional disciplinary research. These researchers therefore often face the challenge of assessing and understanding the complex dynamics of SES, while promoting transdisciplinary processes that facilitate knowledge exchange across disciplines and between academic and non-academic actors (Balvanera et al. 2017).

In generating policy-relevant, solutions-oriented and socially robust knowledge, SES research often involves processes of knowledge co-production. Knowledge co-production is defined as an iterative and collaborative process involving diverse types of expertise, knowledge and actors to produce context-specific knowledge and pathways towards a sustainable future (Norström et al. 2020). Knowledge co-production is premised on the idea that knowledge and action are intertwined (Miller and Wyborn 2018), and can lead to the emergence of potential solutions and open the space for stakeholders to engage with these solutions and co-create strategic plans (Eelderink, Vervoot, and Van Laerhoven 2020). It provides a platform for mutual learning through processes of engagement and negotiation that include different actors and incorporate their diverse and divergent knowledge systems, perspectives, values and interests (Caniglia et al. 2020). These collective and collaborative practices run throughout the entire transdisciplinary research process, from problem formulation, to communication of results or outputs, to design of actions (Wheeler and Root-Bernstein 2020). In these cases, SES research can be seen as 'action-oriented research' with the power to unlock innovative thinking and find the best-fitting strategies to deal with sustainability challenges and problems.

Monitoring, evaluation and learning (MEL) is often incorporated into transdisciplinary SES research programmes to measure the impact of implementation, and identify lessons for future policy and planning (Taylor et al. 2016). When the idea of MEL first emerged, it was conceived within the international development sector as a form of 'evaluation for accountability' or 'summative evaluation' whereby a donor or sponsor is provided with the necessary information to demonstrate that the funded intervention has delivered on its stated ideas and objectives. There has been a gradual shift in the last 20 years to respond to the needs of development funders, planners and practitioners to learn from their previous experiences. This shift recognises that learning plays an essential role in the long-term sustainability of an organisation or initiative. This has given rise to 'evaluation for learning' and has led to an increasing emphasis on the translation of new knowledge into better policy and practice (Morris and Lawrence 2010). There are two main routes to learning that may be applied to SES research: (a) reflexive learning, which is conscious reflection on one's own experience, and (b) learning through exchanging and sharing ideas with other stakeholders. Monitoring and evaluation provides important data and experiences that can contribute to this learning by helping to identify obstacles and highlight possible changes that need to be made as an initiative evolves and develops.

Action-oriented SES research often includes practices of reflexivity and reciprocity. Reflexivity involves critical reflection on the assumptions, values and concepts underlying the research process, as well as a critical analysis of the power asymmetries between different forms of knowledge and actors (Norström et al. 2020; Turnhout et al. 2020). Reflexivity therefore requires the examination of researchers' embeddedness in power-laden transdisciplinary processes, questioning the limitations and potential implications of the researcher's position. Reciprocity entails the empowerment of actors as equal partners during the 
research process, and the provision of effective and useful outcomes to non-academic actors (Iniesta-Arandia et al. 2016). These practices have been extensively fostered by feminist scholars (Hesse-Biber and Piateli 2012; Iniesta-Arandia et al. 2016).

Social-ecological systems research, especially if it is action-oriented research, typically produces a broader set of outputs than conventional disciplinary research. While academic publications remain important, the process of engagement with stakeholders, and the shared understanding of a problem and system generated through co-production processes, may be as important. In fact, one way of measuring the success of SES research when embedded in transdisciplinary processes is to assess how much the research has supported the coproduction of knowledge (from the research questions to the dissemination of findings), and the identification of solutions and design of actions (Mauser et al. 2013; Balvanera et al. 2017). In this sense, stakeholder dialogues and engagement in various management forums may be as important as scientific outputs. Consequently, SES research is often communicated in multiple formats in order to reach a range of audiences and stakeholders (Goring et al. 2014). Examples of these formats are scientific articles and reports, policy briefs, popular science articles and, increasingly, videos and engagement with the arts (see Chapter 33 for further discussion).

\section{Conclusion}

Many researchers engage in SES research because they are passionate about addressing the intertwined social and ecological sustainability issues facing society. Social-ecological systems research therefore often requires engaging in larger transdisciplinary initiatives where the lines between research and action are blurred. Any engagement with change processes on the ground requires a thorough understanding of the issues, history and context of the particular place in which one is working and of the diverse actors involved. Engaged SES research is conducted at scales ranging from local places to the global commons, recognising that SES are truly intertwined, across temporal and spatial scales (Cash et al. 2006; Balvanera et al. 2017; Österblom et al. 2017). In this book we discuss SES research methods that span these scales and contexts, focusing on approaches used in SES research rather than primarily in SES governance or management contexts.

This chapter is the first of four introductory chapters comprising Part 1 of the handbook. In this chapter we introduced the concept of SES, and how it is rooted in an understanding of complex adaptive systems and of humanity intertwined with and embedded in the biosphere. Chapter 2 delves deeper into the implications of a complex adaptive systems-based approach for SES research and research methods, while Chapter 3 discusses SES research in practice. With this background in hand, Chapter 4 introduces the structure for different SES research methods covered in the core of the book in Part 2 (Chapters 5-32). Part 3 of the book (Chapter 33) provides a synthesis and reflection on current SES research methods, and potential future areas of development.

\section{Acknowledgements}

Reinette Biggs received support from the South African Research Chairs Initiative (SARChI) (grant 98766), the Guidance for Resilience in the Anthropocene: Investments for Development (GRAID) project funded by the Swedish International Development Agency (Sida) and a Young Researchers Grant from the Vetenskapsrådet in Sweden (grant 621-20145137). Hayley Clements is funded by a Jennifer Ward Oppenheimer Research Grant and 
Kone Foundation. Alta de Vos received support from a Rhodes University Council Grant. Rika Preiser's salary was co-funded by the Swedish International Development Agency's (Sida) GRAID and Swedbio programmes. Maja Schlüter received funding from the European Research Council under the European Union's Horizon 2020 research and innovation programme (grant agreement no. 682472 - MUSES).

\section{References}

Adger, W.N., N.W. Arnell, and E.L. Tompkins. 2005. 'Successful Adaptation to Climate Change Across Scales.' Global Environmental Change 15(2): 77-86. doi:10.1016/j.gloenvcha.2004.12.005.

Anderies, J.M., O. Barreteau, and U. Brady. 2019. 'Refining the Robustness of Social-Ecological Systems Framework for Comparative Analysis of Coastal System Adaptation to Global Change.' Regional Environmental Change 19(7): 1891-1908. doi:10.1007/s10113-019-01529-0.

Anderies, J.M., M.A. Janssen, and E. Ostrom. 2004. 'A Framework to Analyze the Robustness of Social-Ecological Systems from an Institutional Perspective.' Ecology and Society 9(1): 18. www. ecologyandsociety.org/vol9/iss1/art18.

Baggio, J.A., K. Brown, and D. Hellebrandt. 2015. 'Boundary Object or Bridging Concept? A Citation Network Analysis of Resilience.' Ecology and Society 20(2): 2. doi:10.5751/ES-07484-200202.

Bahru, B.A., C. Bosch, R. Birner, and M. Zeller. 2019. 'Drought and Child Undernutrition in Ethiopia: A Longitudinal Path Analysis.' PLoS ONE 14(6): e0217821. doi:10.1371/journal.pone.0217821.

Balvanera, P., T.M. Daw, T. Gardner, B. Martín-López, A.V. Norström, C. Ifejika Speranza, M. Spierenburg et al. 2017. 'Key Features for more Successful Place-based Sustainability Research on Social-Ecological Systems: A Programme on Ecosystem Change and Society (PECS) Perspective.' Ecology and Society 22(1): 14. doi:10.5751/ES-08826-220114.

Ban, N.C., G.G. Gurney, N.A. Marshall, C.K. Whitney, M. Mills, S. Gelcich, N.J. Bennett et al. 2019. 'Well-being Outcomes of Marine Protected Areas.' Nature Sustainability 2(6): 524-532. doi:10.1038/ s41893-019-0306-2.

Barbier, E.B., and J.P. Hochard. 2018. 'The Impacts of Climate Change on the Poor in Disadvantaged Regions.' Review of Environmental Economics and Policy 12(1): 26-47. doi:10.1093/reep/rex023.

Bateson, G. 1979. Mind and Nature: A Necessary Unit. New York: Bantam Books.

Berkes, F., ed. 1989. Common Property Resources: Ecology of Community-based Sustainable Development. London: Belhaven Press.

Berkes, F., J. Colding, and C. Folke, eds. 2003. Navigating Social-Ecological Systems: Building Resilience for Complexity and Change. Cambridge: Cambridge University Press.

Berkes, F., and C. Folke, eds. 1998. Linking Social and Ecological Systems: Management Practices and Social Mechanisms for Building Resilience. Cambridge: Cambridge University Press.

Berkes, F., and H. Ross. 2016. 'Panarchy and Community Resilience: Sustainability Science and Policy Implications.' Environmental Science and Policy 61: 185-193. doi:10.1016/j.envsci.2016.04.004.

Biggs, R., G.D. Peterson, and J. Rocha. 2018. 'The Regime Shifts Database: A Framework for Analyzing Regime Shifts in Social-Ecological Systems.' Ecology and Society 23(3): 9. doi:10.5751/ ES-10264-230309.

Biggs, R., M. Schlüter, and M.L. Schoon. 2015. 'An Introduction to the Resilience Approach and Principles to Sustain Ecosystem Services in Social-Ecological Systems.' In Principles for Building Resilience: Sustaining Ecosystem Services in Social-Ecological Systems, edited by R. Biggs, M. Schlüter, and M.L. Schoon, 1-31. Cambridge: Cambridge University Press.

Binder, C.R., J. Hinkel, P.W.G. Bots, and C. Pahl-Wostl. 2013. 'Comparison of Frameworks for Analyzing Social-Ecological Systems.' Ecology and Society 18(4): 26. doi:10.5751/ES-05551-180426.

Bodin, Ö. 2017. 'Collaborative Environmental Governance: Achieving Collective Action in Social-Ecological Systems.' Science 357: eaan1114. doi:10.1126/science.aan1114.

Caniglia, C., C. Luederitz, T. von Wirth, I. Fazey, B. Martín-López, K. Hondrila, A. König et al. 2020 (in press). 'A Pluralistic and Integrated Approach to Action-oriented Knowledge for Sustainability.' Nature Sustainability. doi:10.1038/s41893-020-00616-z.

Carpenter, S.R., C. Folke, A.V. Norström, O. Olsson, L. Schultz, B. Agarwal, P. Balvanera et al. 2012. 'Program on Ecosystem Change and Society: An International Research Strategy for Integrated Social-Ecological Systems.' Current Opinion in Environmental Sustainability 4(1): 134-138. doi:10.1016/j.cosust.2012.01.001. 
Carrasco, L.R., J. Chan, F.L. McGrath, and L.T.P. Nghiem. 2017. 'Biodiversity Conservation in a Telecoupled World.' Ecology and Society 22(3): 24. doi:10.5751/ES-09448-220324.

Cash, D.W., W.N. Adger F. Berkes, P. Garden, L. Lebel, P. Olsson, and L. Pritchard. 2006. 'Scale and Cross-scale Dynamics: Governance and Information in a Multilevel World.' Ecology and Society 11(2): 8. www.jstor:stable/26265993.

Chan, K.M., P. Balvanera, K. Benessaiah, M. Chapman, S. Díaz, E. Gómez-Baggethun, R. Gould et al. 2016. 'Opinion: Why Protect Nature? Rethinking Values and the Environment.' Proceedings of the National Academy of Sciences 113(6): 1462-1465. doi:10.1073/pnas.1525002113.

Cilliers, P. 2001. 'Boundaries, Hierarchies and Networks in Complex Systems.' International Journal of Innovation Management 5(2): 135-147. doi:10.1142/S1363919601000312.

Cinner, J.E., C. Huchery, M.A. MacNeil, N.A. Graham, T.R. McClanahan, J. Maina, E. Maire et al. 2016. 'Bright Spots among the World's Coral Reefs.' Nature 535(7612): 416-419. doi:10.1038/nature18607.

Clark, W.C., P.J. Crutzen, and H.J. Schellnhuber. 2004. 'Science for Global Sustainability.' In Earth System Analysis for Sustainability, edited by H.J. Schellnhuber, P.J. Crutzen, W.C. Clark, C. Martin, and H. Hermann, 1-28. Cambridge: MIT Press.

Clark, W.C., and A.G. Harley. 2020 (in press). 'Sustainability Science: Towards a Synthesis.' Annual Review of Environment and Resources 45.

Clark, W.C., and R.E. Munn, eds. 1986. Sustainable Development of the Biosphere. Cambridge: Cambridge University Press.

Colding, J., and S. Barthel. 2019. 'Exploring the Social-Ecological Systems Discourse 20 Years Later.' Ecology and Society 24(1): 2. doi:10.5751/ES-10598-240102.

Cosens, B.A., L.H. Gunderson, and B.C. Chaffin. 2018. 'Introduction to the Special Feature Practicing Panarchy: Assessing Legal Flexibility, Ecological Resilience, and Adaptive Governance in Regional Water Systems Experiencing Rapid Environmental Change.' Ecology and Society 23(1): 4. doi:10.5751/ES-09524-230104.

Costanza, R., ed. 1991. Ecological Economics: The Science and Management of Sustainability. New York: Columbia University Press.

Costinot, A., J. Vogel, and S. Wang. 2012. 'Global Supply Chains and Wage Inequality.' American Economic Review 102(3): 396-401. doi.10.1257/aer.102.3.396.

Cox, M. 2014. 'Understanding Large Social-Ecological Systems: Introducing the Social-ecological System MAD Project.' International Journal of the Commons 8(2): 265-276. doi:10.18352/ijc.406.

Cox, M., G. Arnold, and S. Villamayor-Tomas. 2010. 'A Review of Design Principles for Community-based Natural Resource Management.' Ecology and Society 15(4): 38. www.jstor.org/ stable/26268233.

Crona, B.I., T. van Holt, M. Petersson, T.M. Daw, and E. Buchary. 2015. 'Using Social-Ecological Syndromes to Understand Impacts of International Seafood Trade on Small-scale Fisheries.' Global Environmental Change 35: 162-175. doi:10.1016/j.gloenvcha.2015.07.006.

Crutzen, P.J. 2006. 'The "Anthropocene".' In Earth system Science in the Anthropocene, edited by E. Ehlers and T. Krafft, 13-18. Berlin: Springer. doi:10.1007/3-540-26590-2_3.

Cumming, G.S. 2014. 'Theoretical Frameworks for the Analysis of Social-Ecological Systems.' In Social-Ecological Systems in Transition, Global Environmental Studies, edited by S. Sakai and C. Umetsu, 3-24. Tokyo: Springer.

Cumming, G.S., C.R. Allen, N.C. Ban, D. Biggs, H.C. Biggs, D.H. Cumming, A. de Vos et al. 2015. 'Understanding Protected Area Resilience: A Multi-scale, Social-ecological Approach.' Ecological Applications 25(2): 299-319. doi:10.1890/13-2113.1.

Cumming, G.S., G. Epstein, J.M. Anderies, C.I. Apetrei, J. Baggio, Ö. Bodin, S. Chawla et al. 2020. 'Advancing Understanding of Natural Resource Governance Using the Social-Ecological Systems Framework: A Post-Ostrom Research Agenda.' Current Opinion in Environmental Sustainability 44: 26-34. doi:10.1016/j.cosust.2020.02.005.

Dai, A. 2013. 'Increasing Drought under Global Warming in Observations and Models.' Nature Climate Change 3(1): 52-58. doi:10.1038/nclimate1633.

Davidson-Hunt, I.J., and F. Berkes. 2003. 'Nature and Society through the Lens of Resilience: Toward a Human-in-Ecosystem Perspective.' In Navigating Social-Ecological Systems: Building Resilience for Complexity and Change, edited by F. Berkes, J. Colding, and C. Folke, 53-82. Cambridge: Cambridge University Press.

De Vos, A., R. Biggs, and R. Preiser. 2019. 'Methods for Understanding Social-Ecological Systems: A Review of Place-based Studies.' Ecology and Society 24(4): 16. doi:10.5751/es-11236-240416. 
Díaz, S., S. Demissew, J. Carabias, C. Joly, M. Lonsdale, N. Ash, A. Larigauderie et al. 2015. 'The IPBES Conceptual Framework - Connecting Nature and People.' Current Opinion in Environmental Sustainability 14: 1-16. doi:10.1016/j.cosust.2014.11.002.

Díaz, S., U. Pascual, M. Stenseke, B. Martín-López, R.T. Watson, Z. Molnár, R. Hill et al. 2018. 'Assessing Nature's Contributions to People.' Science 359(6373): 270-272. doi:10.1126/science.aap8826.

Dietz, T., E. Ostrom, and P.C. Stern. 2003. 'The Struggle to Govern the Commons.' Science 302(5652): 1907-1912. www.jstor.org/stable/3835713.

Eelderink, M., J.M. Vervoort, and F. van Laerhoven. 2020. 'Using Participatory Action Research to Operationalize Critical Systems Thinking in Social-Ecological Systems.' Ecology and Society 25(1): 16. doi:10.5751/ES-11369-250116.

Epstein, G., J.M. Vogt, S.K. Mincey, M. Cox, and B. Fischer. 2013. 'Missing Ecology: Integrating Ecological Perspectives with the Social-ecological System Framework.' International Journal of the Commons 7(2): 432-453. doi:10.18352/ijc.371.

Everard, M., P. Johnston, D. Santillo, and C. Staddon. 2020. 'The Role of Ecosystems in Mitigation and Management of Covid-19 and other Zoonoses.' Environmental Science and Policy 111: 7-17. doi:10.1016/j.envsci.2020.05.017.

Fischer, J., T.A. Gardner, E.M. Bennett, P. Balvanera, R. Biggs, S.R. Carpenter, T.M. Daw et al. 2015. 'Advancing Sustainability through Mainstreaming a Social-Ecological Systems Perspective.' Current Opinion in Environmental Sustainability 14: 144-149. doi:10.1016/j.cosust.2015.06.002.

Folke, C. 2006. 'Resilience: The Emergence of a Perspective for Social-Ecological Systems Analyses.' Global Environmental Change 16: 253-267. doi:10.1016/j.gloenvcha.2006.04.002.

Folke, C., and F. Berkes. 1998. 'Understanding Dynamics of Ecosystem-Institution Linkages for Building Resilience.' Stockholm, Sweden: Beijer Discussion Paper No. 112. Stockholm: Beijer Institute of Ecological Economics, The Royal Academy of Sciences.

Folke, C., R. Biggs, A.V. Norström, B. Reyers, and J. Rockström. 2016. 'Social-ecological Resilience and Biosphere-based Sustainability Science.' Ecology and Society 21(3): 41. doi:10.5751/ES-08748-210341.

Folke, C., S.R. Carpenter, T. Elmqvist, L.H. Gunderson, C.S. Holling, and B. Walker. 2002. 'Resilience and Sustainable Development: Building Adaptive Capacity in a World of Transformations.' Ambio 31(5): 437-440. doi:10.1579/0044-7447-31.5.437.

Folke, C., S.R. Carpenter, B. Walker, M. Scheffer, T. Chapin, and J. Rockström. 2010. 'Resilience Thinking: Integrating Resilience, Adaptability and Transformability.' Ecology and Society 15(4): 20. www.ecologyandsociety.org/vol15/iss4/art20.

Folke, C., T. Hahn, P. Olsson, and J. Norberg. 2005. 'Adaptive Governance of Social-Ecological Systems.' Annual Review of Environment and Resources 30: 441-473. doi:10.1146/annurev.energy. 30.050504.144511.

Folke, C., A. Jansson, J. Rockström, P. Olsson, S.R. Carpenter, F.S. Chapin, A-S. Crépin et al. 2011. 'Reconnecting to the Biosphere.' Ambio 40(7): 719. doi:10.1007/s13280-011-0184-y.

Friis, C., and J.Ø. Nielsen. 2017. 'On the System. Boundary Choices, Implications, and Solutions in Telecoupling Land Use Change Research.' Sustainability 9(6): 974. doi:10.3390/su9060974.

Galappaththi, E.K., J.D. Ford, E.M. Bennett, and F. Berkes. 2019. 'Climate Change and Community Fisheries in the Arctic: A Case Study from Pangnirtung, Canada.' Journal of Environmental Management 250: 109534. doi:10.1016/j.jenvman.2019.109534.

Galaz, V., B. Crona, A. Dauriach, J-B. Jouffray, H. Österblom, and J. Fichtner. 2018. 'Tax Havens and Global Environmental Degradation.' Nature Ecology and Evolution 2(9): 1352-1357. doi:10.1038/ s41559-018-0497-3.

Galaz, V., F. Moberg, E-K. Olsson, E. Paglia, and C. Parker. 2011. 'Institutional and Political Leadership Dimensions of Cascading Ecological Crises.' Public Administration 89(2): 361-380. doi:10.1111/j.1467-9299.2010.01883.x.

Geobey, S., and K.A. McGowan. 2019. 'Panarchy, Ontological and Epistemological Phenomena, and the Plague.' Ecology and Society 24(4): 23. doi:10.5751/ES-11089-240423.

Goring, S.J., K.C. Weathers, W.K. Dodds, P.A. Soranno, L.C. Sweet, K.S. Cheruvelil, J.S. Kominoski, J. Rüegg, A.M. Thorn, and R.M. Utz. 2014. 'Improving the Culture of Interdisciplinary Collaboration in Ecology by Expanding Measures of Success.' Frontiers in Ecology and the Environment 12(1): 39-47. doi:10.1890/120370.

Green, J.M.H., S.A. Croft, A.P. Durán, A.P. Balmford, N.D. Burgess, S. Fick, T.A. Gardner et al. 2019. 'Linking Global Drivers of Agricultural Trade to on-the-ground Impacts on Biodiversity.' Proceedings of the National Academy of Sciences 116(46): 23202-23208. doi:10.1073/pnas.1905618116. 
Guerbois, C., U. Brady, A.G. de Swardt, and C. Fabricius. 2019. 'Nurturing Ecosystem-based Adaptations in South Africa's Garden Route: A Common Pool Resource Governance Perspective.' Regional Environmental Change 19(7): 1849-1863. doi:10.1007/s10113-019-01508-5.

Guo, Y., A. Gasparrini, S. Li, F. Sera, A.M. Vicedo-Cabrera, M.Z.S. Coelho, P.H.N. Saldiva et al. 2018. 'Quantifying Excess Deaths Related to Heatwaves under Climate Change Scenarios: A Multicountry Time Series Modelling Study.’ PLoS Medicine 15(7): e1002629. doi:10.1371/journal.pmed.1002629.

Gunderson, L.H., B.A. Cosens, B.C. Chaffin, C.A.T. Arnold, A.K. Fremier, A.S. Garmestani, R.K. Craig et al. 2017. 'Regime Shifts and Panarchies in Regional Scale Social-ecological Water Systems.' Ecology and Society 22(1): 31. doi:10.5751/ES-08879-220131.

Gunderson, L.H., and C.S. Holling, eds. 2002. Panarchy: Understanding Transformations in Human and Natural Systems. Washington: Island Press.

Gunderson, L.H., C.S. Holling, and S.S. Light, eds. 1995. Barriers and Bridges to the Renewal of Ecosystems and Institutions. New York: Columbia University Press.

Gurney, G.G., E.S. Darling, S.D. Jupiter, S. Mangubhai, T.R. McClanahan, P. Lestari, S. Pardede et al. 2019. 'Implementing a Social-Ecological Systems Framework for Conservation Monitoring: Lessons from a Multi-country Coral Reef Program.' Biological Conservation 240: 108298. doi:10.1016/j. biocon.2019.108298.

Gutiérrez, N.L., R. Hilborn, and O. Defeo. 2011. 'Leadership, Social Capital and Incentives Promote Successful Fisheries.' Nature 470: 386-389. doi:10.1038/nature09689.

Hamann, M., K. Berry, T. Chaigneau, T. Curry, R. Heilmayr, P.J.G. Henriksson, J. Hentati-Sundberg et al. 2018. 'Inequality and the Biosphere.' Annual Review of Environment and Resources 43(1): 61-83. doi:10.1146/annurev-environ-102017-025949.

Hamann, M., R. Biggs, and B. Reyers. 2015. 'Mapping Social-Ecological Systems: Identifying "Green-loop" and "Red-loop" Dynamics Based on Characteristic Bundles of Ecosystem Service Use.' Global Environmental Change 34: 218-226. doi:10.1016/j.gloenvcha.2015.07.008.

Herrero-Jáuregui, C., C. Arnaiz-Schmitz, M.F. Reyes, M. Telesnicki, I. Agramonte, M.H. Easdale, M.F. Schmitz,M.Aguiar,A.Gómez-Sal, andC.Montes.2018. 'WhatDoWeTalkAboutWhen WeTalkAbout Social-Ecological Systems? A Literature Review.' Sustainability 10(8): 2950. doi:10.3390/su10082950.

Hertz, T., M. Mancilla García, and M. Schlüter. 2020. 'From Nouns to Verbs: How Process Ontologies Enhance our Understanding of Social-Ecological Systems Understood as Complex Adaptive Systems.' People and Nature 2(2): 328-338. doi:10.1002/pan3.10079.

Hesse-Biber, S., and D. Piatelli. 2012. 'The Feminist Practice of Holistic Reflexivity.' In Handbook of Feminist Research: Theory and Praxis, edited by S. Hesse-Biber. Thousand Oaks: Sage.

Holdschlag, A., and B.M. Ratter. 2016. 'Caribbean Island States in a Social-ecological Panarchy? Complexity Theory, Adaptability and Environmental Knowledge Systems.' Anthropocene 13: 80-93. doi:10.1016/j.ancene.2016.03.002.

Holling, C.S. 1973. 'Resilience and Stability of Ecological Systems.' Annual Review of Ecology and Systematics 4: 1-23. doi:10.1146/annurev.es.04.110173.000245.

Horcea-Milcu, A-I., B. Martín-López, D.P.M. Lam, and D.J. Lang. 2020. 'Research Pathways to Foster Transformation: Linking Sustainability Science and Social-Ecological Systems Research.' Ecology and Society 25(1): 13. doi:10.5751/ES-11332-250113.

Hules, M., and S.J. Singh. 2017. 'India's Land Grab Deals in Ethiopia: Food Security or Global Politics?' Land Use Policy 60: 343-351, doi:10.1016/j.landusepol.2016.10.035.

Hull, V., and J. Liu. 2018. 'Telecoupling: A New Frontier for Global Sustainability.' Ecology and Society 23(4): 41. doi:10.5751/ES-10494-230441.

Iniesta-Arandia, I., F. Ravera, S. Buechler, I. Díaz-Reviriego, M.E. Fernández-Giménez, M.G. Reed, M. Thompson-Hall et al. 2016. 'A Synthesis of Convergent Reflections, Tensions and Silences in Linking Gender and Global Environmental Change Research.' Ambio 45(3): 383-393. doi:10.1007/ s13280-016-0843-0.

Jiren, T.S., I. Dorresteijn, J. Hanspach, J. Schultner, A. Bergsten, A. Manlosa, N. Jager, F. Senbeta, and J. Fischer. 2020. 'Alternative Discourses Around the Governance of Food Security: A Case Study from Ethiopia.' Global Food Security 24: 100338. doi:10.1016/j.gfs.2019.100338.

Kelly, R., M. Mackay, K.L. Nash, C. Cvitanovic, E.H. Allison, D. Armitage, A. Bonn et al. 2019. 'Ten Tips for Developing Interdisciplinary Socio-ecological Researchers.' Socio-ecological Practice Research 1(2): 149-161. doi:10.1007/s42532-019-00018-2.

Keys, P.W., V. Galaz, M. Dyer, N. Matthews, C. Folke, M. Nyström, and S.E. Cornell. 2019. 'Anthropocene Risk.' Nature Sustainability 2(8): 667-673. doi:10.1038/s41893-019-0327-x. 
Krausmann, F., K-H. Erb, S. Gingrich, H. Haberl, A. Bondeau, V. Gaube, C. Lauk, C. Plutzar, and T.D. Searchinger. 2013. 'Global Human Appropriation of Net Primary Production doubled in the 20th Century.' Proceedings of the National Academy of Sciences 110(25): 10324-10329. doi:10.1073/ pnas.1211349110.

Kummu, M., P. Kinnunen, E. Lehikoinen, M. Porkka, C. Queiroz, E. Röös, M. Troell, and C. Weil. 2020. 'Interplay of Trade and Food System Resilience: Gains on Supply Diversity Over Time at the Cost of Trade Independency.' Global Food Security 24: 100360. doi:10.1016/j.gfs.2020.100360.

Lade, S.J., A. Tavoni, S.A. Levin, and M. Schlüter. 2013. 'Regime Shifts in a Social-ecological System.' Theoretical Ecology 6(3): 359-372. doi:10.1007/s12080-013-0187-3.

Lambin, E.F., and P. Meyfroidt. 2011. 'Global Land Use Change, Economic Globalization, and the Looming Land Scarcity.' Proceedings of the National Academy of Sciences 108(9): 3465-3472. doi:10.1073/pnas.1100480108.

Lambin, E.F., B.L. Turner, H.J. Geist, S.B. Agbola, A. Angelsen, J.W. Bruce, O.T. Coomes et al. 2001. 'The Causes of Land-use and Land-cover Change: Moving Beyond the Myths.' Global Environmental Change 11(4): 261-269. doi:10.1016/S0959-3780(01)00007-3.

Lang, D.J., A. Wiek, M. Bergmann, M. Stauffacher, P. Martens, P. Moll, M. Swilling, and C.J. Thomas. 2012. 'Transdisciplinary Research in Sustainability Science: Practice, Principles, and Challenges.' Sustainability Science 7(1): 25-43. doi:10.1007/s11625-011-0149-x.

Lansing, J.S. 2003. 'Complex Adaptive Systems.' Annual Review of Anthropology 32(1): $183-204$. doi:10.1146/annurev.anthro.32.061002.093440.

Lenzen, M., D. Moran, K. Kanemoto, B. Foran, L. Lobefaro, and A. Geschke. 2012. 'International Trade Drives Biodiversity Threats in Developing Nations.' Nature 486(7401): 109-112. doi:10.1038/ nature11145.Levin, S.A. 1999. 'Fragile Dominion Complexity and the Commons.' Journal of Ecology 88(1): 181. doi:10.1046/j.1365-2745.2000.00425-5.x.

Levin, S.A., T. Xepapadeas, A-S. Crépin, J. Norberg, A.D. Zeeuw, C. Folke, T. Hughes et al. 2013. 'Social-Ecological Systems as Complex Adaptive Systems: Modeling and Policy Implications.' Environment and Development Economics 18(2): 111-132. doi:10.1017/S1355770X12000460.

Liu, J., T. Dietz, S.R. Carpenter, M. Alberti, C. Folke, M. Alberti, C.L. Redman et al. 2007a. 'Coupled Human and Natural Systems.' Ambio 36(8): 639-649. doi:10.1579/0044-7447(2007)36[639:CH ANS]2.0.CO;2.

Liu, J., T. Dietz, S.R. Carpenter, M. Alberti, C. Folke, E. Moran, A.C. Pell et al. 2007b. 'Complexity of Coupled Human and Natural Systems.' Science 317(5844): 1513-1516. doi:10.1126/science.1144004.

Liu, J., Y. Dou, M. Batistella, E. Challies, T. Connor, C. Friis, J.D.A. Millington et al. 2018. 'Spillover Systems in a Telecoupled Anthropocene: Typology, Methods, and Governance for Global Sustainability.' Current Opinion in Environmental Sustainability 33: 58-69. doi:10.1016/j.cosust.2018.04.009.

Liu, J., V. Hull, M. Batistella, R. DeFries, T. Dietz, F. Fu, T.W. Hertel et al. 2013. 'Framing Sustainability in a Telecoupled World.' Ecology and Society 18(2): 26. doi:10.5751/ES-05873-180226.

Liu, J., H. Mooney, V. Hull, S.J. Davis, J. Gaskell, T. Hertel, J. Lubchenco et al. 2015. 'Systems Integration for Global Sustainability.' Science 347(6225): 963. doi:10.1126/science.1258832.

Liu, J., W. Yang, and S. Li. 2016. 'Framing Ecosystem Services in the Telecoupled Anthropocene.' Frontiers in Ecology and the Environment 14(1): 27-36. doi:10.1002/16-0188.1.

Mancilla García, M., T. Hertz, M. Schlüter, R. Preiser, and M. Woermann. 2020. 'Adopting Process-relational Perspectives to Tackle the Challenges of Social-Ecological Systems Research.' Ecology and Society 25(1): 29. doi:10.5751/ES-11425-250129.

Masterson, V.A., S. Vetter, T. Chaigneau, T.M. Daw, O. Selomane, M. Hamann, G.Y. Wong et al. 2019. 'Revisiting the Relationships Between Human Well-being and Ecosystems in Dynamic Social-Ecological Systems: Implications for Stewardship and Development.' Global Sustainability 2: E8. doi:10.1017/S205947981900005X.

Mauser, W., G. Klepper, M. Rice, Bettina, S. Schmalzbauer, H. Hackmann, R. Leemans, and H. Moore. 2013. 'Transdisciplinary Global Change Research: The Co-creation of Knowledge for Sustainability.' Current Opinion in Environmental Sustainability 5(3-4): 420-431. doi:10.1016/j. cosust.2013.07.001.

McGinnis, M.D. 2011. 'An Introduction to IAD and the Language of the Ostrom Workshop: A Simple Guide to a Complex Framework.' Policy Studies Journal 39(1): 169-183. doi:10.1111/j.1541-0072.2010.00401.x.

Miller, C.A., and C. Wyborn. 2018. 'Co-production in Global Sustainability: Histories and Theories.' Environmental Science and Policy 113: 88-95. doi:10.1016/j.envsci.2018.01.016. 
Milly, P.C.D., R.T. Wetherald, K.A. Dunne, K.A, and T.L. Delworth. 2002. 'Increasing Risk of Great Floods in a Changing Climate.' Nature 415(6871): 514-517. doi:10.1038/415514a.

Mohamed, A.A. 2017. 'Food Security Situation in Ethiopia: A Review Study.' International Journal of Health Economics and Policy 2(3): 86-96. www.sciencepublishinggroup.com/j/hep.

Morris, J., and A. Lawrence. 2010. 'Learning from Monitoring and Evaluation - A Blueprint for an Adaptive Organisation.' Social and Economic Research Group. www.forestresearch.gov.uk/research/ learning-from-monitoring-and-evaluation-a-blueprint-for-an-adaptive-organisation.

Naylor, L.A., U. Brady, T. Quinn, K. Brown, and J.M. Anderies. 2019. 'A Multiscale Analysis of Social-ecological System Robustness and Vulnerability in Cornwall, UK.' Regional Environmental Change 19(7): 1835-1848. doi:10.1007/s10113-019-01530-7.

Nicholls, R.J. 2004. 'Coastal Flooding and Wetland Loss in the 21st century: Changes Under the SRES Climate and Socio-economic Scenarios.' Global Environmental Change 14(1): 69-86. doi:10.1016/j. gloenvcha.2003.10.007.

Norberg, J., and G.S. Cumming. 2008. Complexity Theory for a Sustainable Future. New York: Columbia University Press.

Norström, A.V., C. Cvitanovic, M.F. Löf, S. West, C. Wyborn, P. Balvanera, A.T. Bednarek et al. 2020. 'Principles for Knowledge Co-Production in Sustainability Research.' Nature Sustainability 3: 182-190. doi:10.1038/s41893-019-0448-2.

Nyström, M., J-B. Jouffray, A.V. Norström, B. Crona, P.S. Jørgensen, S.R. Carpenter, Ö. Bodin, V. Galaz, and C. Folke. 2019. 'Anatomy and Resilience of the Global Production Ecosystem.' Nature 575(7781): 98-108. doi:10.1038/s41586-019-1712-3.

O'Callaghan-Gordo, C., and J.M. Antó. 2020. 'COVID-19: The Disease of the Anthropocene.' Environmental Research 187: 109683. doi:10.1016/j.envres.2020.109683.

Odum, E.P. 1989. Ecology and our Endangered Life-support Systems. Sunderland: Sinauer.

Oliver, E.C.J., M.G. Donat, M.T. Burrows, P.J. Moore, D.A. Smale, L.V. Alexander, J.A. Benthuysen et al. 2018. 'Longer and More Frequent Marine Heatwaves over the Past Century.' Nature Communications 9(1): 1-12. doi:10.1038/s41467-018-03732-9.

Olsson, P., V. Galaz, and W. J. Boonstra. 2014. 'Sustainability Transformations: A Resilience Perspective.' Ecology and Society 19(4): 1. doi:10.5751/ES-06799-190401.

Olsson, P., L.H. Gunderson, S.R. Carpenter, P. Ryan, L. Lebel, C. Folke, and C.S. Holling. 2006. 'Shooting the Rapids: Navigating Transitions to Adaptive Governance of Social-Ecological Systems.' Ecology and Society 11(1): 18. www.ecologyandsociety.org/vol11/iss1/art18.

Orach, K., and Schlüter, M. n.d. 'Understanding the Dynamics of Fish Politics: The Role of Diverse Actor Interactions in Transformations Towards Co-management.' Global Environmental Change (submitted).

Österblom, H., and C. Folke. 2013. 'Emergence of Global Adaptive Governance for Stewardship of Regional Marine Resources.' Ecology and Society 18(2): 4. doi:10.5751/ES-05373-180204.

Österblom, H., C. Folke, J-B. Jouffray, and J. Rockström. 2017. 'Emergence of a Global ScienceBusiness Initiative for Ocean Stewardship.' Proceedings of the National Academy of Sciences USA 114: 9038-9043. doi:10.1073/pnas.1704453114.

Ostrom, E. 1990. Governing the Commons: The Evolution of Institutions for Collective Action. Cambridge: Cambridge University Press.

Ostrom, E. 2007. 'A Diagnostic Approach for Going beyond Panaceas.' Proceedings of the National Academy of Sciences 104(39): 15181-15187. doi:10.1073/pnas.0702288104.

Ostrom, E. 2009. 'A General Framework for Analyzing Sustainability of Social-Ecological Systems.' Science 325(5939): 419-422. doi:10.1126/science.1172133.

Palomo I., M. Felipe-Lucía, E.M. Bennet, B. Martín-López, and U. Pascual. 2016. 'Disentangling the Pathways and Effects of Ecosystem Service Co-production.' Advances in Ecological Research 54: 245-283. doi:10.1016/bs.aecr.2015.09.003.

Partelow, S. 2018. 'A Review of the Social-Ecological Systems Framework: Applications, Methods, Modifications, and Challenges.' Ecology and Society 23(4): 36. doi:10.5751/ES-10594-230436.

Pereira, L., E.M. Bennett, R. Biggs, G.D. Peterson, T. McPhearson, A.V. Norström, P. Olsson, R. Preiser, C. Raudsepp-Hearne, and J. Vervoort. 2018. 'Seeds of the Future in the Present: Exploring Pathways for Navigating Towards 'Good' Anthropocenes.' In Urban Planet: Knowledge Towards Sustainable Cities, edited by T. Elmqvist, X. Bai, N. Frantzeskaki, C. Griffith, D. Maddox, T. McPhearson, S. Parnell, P. Romero-Lankao, D. Simon, and M. Watkins, 327-350. Cambridge: Cambridge University Press. https://openaccess.city.ac.uk/id/eprint/19567. 
Potschin, M., and R. Haines-Young. 2011. 'Ecosystem Services: Exploring a Geographical Perspective.' Progress in Physical Geography 35(5): 575-594. doi:10.1177/0309133311423172.

Preiser, R., R. Biggs, A. de Vos, and C. Folke. 2018. 'Social-Ecological Systems as Complex Adaptive Systems: Organizing Principles for Advancing Research Methods and Approaches.' Ecology and Society 23(4): 46. doi:10.5751/ES-10558-230446.

Reyers, B., R. Biggs, G.S. Cumming, T. Elmqvist, A.P. Hejnowicz, and S. Polasky. 2013. 'Getting the Measure of Ecosystem Services: A Social-ecological Approach.' Frontiers in Ecology and the Environment 11(5): 268-273. doi:10.1890/120144.

Reyers, B., C. Folke, M-L. Moore, R. Biggs, and V. Galaz. 2018. 'Social-Ecological Systems Insights for Navigating the Dynamics of the Anthropocene.' Annual Review of Environment and Resources 43: 267-289. doi:10.1146/annurev-environ-110615-085349.

Reyers, B., and E.R. Selig. 2020. 'Global Targets that Reveal the Social-ecological Interdependencies of Sustainable Development.' Nature Ecology and Evolution 4: 1011-1019. doi:10.1038/s41559-020-1230-6.

Rocha, J.C., G.D. Peterson, Ö. Bodin, and S. Levin. 2018. 'Cascading Regime Shifts Within and Across Scales.' Science 362(6421): 1379-1383. doi:10.1126/science.aat7850.

Rogers, K.H., R. Luton, H. Biggs, R. Biggs, S. Blignaut, A.G. Choles, C.G. Palmer, and P. Tangwe. 2013. 'Fostering Complexity Thinking in Action Research for Change in Social-Ecological Systems.' Ecology and Society 18(2): 31. doi:10.5751/ES-05330-180231.

Roux, D.J., J.L. Nel, G. Cundill, and P.O. Farrell. 2017. 'Transdisciplinary Research for Systemic Change: Who to Learn with, What to Learn about and How to Learn.' Sustainability Science 12(5): 711-726. doi:10.1007/s11625-017-0446-0.

Scheffer, M., S.R. Carpenter, J.A. Foley, C. Folke, and B. Walker. 2001. 'Catastrophic Shifts in Ecosystems.' Nature 413(6856): 591-596. doi:10.1038/35098000.

Schill, C., J.M. Anderies, T. Lindahl, C. Folke, S. Polasky, J. Camilo Cárdenas, A-S. Crépin et al. 2019. 'A More Dynamic Understanding of Human Behaviour for the Anthropocene.' Nature Sustainability 2: 1075-1082. doi:10.1038/s41893-019-0419-7.

Schlüter, M., L.J. Haider, S.J. Lade, E. Lindkvist, R. Martin, K. Orach, N. Wijermans, and C. Folke. 2019. 'Capturing Emergent Phenomena in Social-Ecological Systems - An Analytical Framework.' Ecology and Society 24(3): 11. doi:10.5751/ES-11012-240311.

Schmeller, D.S., F. Courchamp, and G. Killeen. 2020. 'Biodiversity Loss, Emerging Pathogens and Human Health Risks.' Biodiversity Conservation. doi:10.1007/s10531-020-02021-6.

Scholz, R. 2011. Environmental Literacy in Science and Society. Cambridge: Cambridge University Press.

Schoon, M.L., and S. van der Leeuw. 2015. 'The Shift Toward Social-Ecological Systems Perspectives: Insights into the Human-Nature Relationship.' Natures Sciences Sociétés 23(2): 166-174. doi:10.1051/ nss/2015034.

Schultz, L., C. Folke, H. Österblom, and P. Olsson. 2015. 'Adaptive Governance, Ecosystem Management, and Natural Capital.' Proceedings of the National Academy of Sciences 112(24): 7369-7374. doi:10.1073/pnas.1406493112.Selomane, O., B. Reyers, R. Biggs, and M. Hamann. 2019. 'Harnessing Insights from Social-Ecological Systems Research for Monitoring Sustainable Development.' Sustainability 11(4): 1190. doi:10.3390/su11041190.

Steffen, W., W. Broadgate, L. Deutsch, O. Gaffney, and C. Ludwig, C. 2015a. 'The Trajectory of the Anthropocene: The Great Acceleration.' The Anthropocene Review 2(1): 81-98. doi:10.1177/2053019614564785.

Steffen, W., Å. Persson, L. Deutsch, J. Zalasiewicz, M. Williams, K. Richardson, C. Crumley et al. 2011. 'The Anthropocene: From Global Change to Planetary Stewardship.' Ambio 40: 739. doi:10.1007/s13280-011-0185-x.

Steffen, W., K. Richardson, J. Rockström, S.E. Cornell, I. Fetzer, E.M. Bennett, R. Biggs et al. 2015b. 'Planetary Boundaries: Guiding Human Development on a Changing Planet.' Science 347(6223): 1259855. doi:10.1126/science. 1259855.

Stoll, J.S., B.I. Crona, M. Fabinyi, and E.R. Farr. 2018. 'Seafood Trade Routes for Lobster Obscure Teleconnected Vulnerabilities.' Frontiers in Marine Science 5: 239. doi:10.3389/fmars.2018.00239.

Sun, J., Y. Tong, and J. Liu. 2017. 'Telecoupled Land-use Changes in Distant Countries.' Journal of Integrative Agriculture 16(2): 368-376. doi:10.1016/S2095-3119(16)61528-9.

Taylor, C., J. Cockburn, M. Rouget, J. Ray-Mukherjee, S. Mukherjee, R. Slotow, D. Roberts, R. Boon, S. O'Donoghue, and E. Douwes. 2016. 'Evaluating the Outcomes and Processes of a Research-Action Partnership: The Need for Continuous Reflective Evaluation.' Bothalia - African Biodiversity and Conservation 46(2): 1-16. doi:10.4102/abc.v46i2.2154. 
Tengö, M., E. Brondizio, T. Elmqvist, P. Malmer, and M. Spierenburg. 2014. 'Connecting Diverse Knowledge Systems for Enhanced Ecosystem Governance: The Multiple Evidence Base Approach.' Ambio 43(5): 579-591. doi:10.1007/s13280-014-0501-3.

Trenberth, K.E., A. Dai, G. van der Schrier, P.D. Jones, J. Barichivich, K.R. Briffa, and J. Sheffield. 2014. 'Global Warming and Changes in Drought.' Nature Climate Change 4(1): 17-22. doi:10.1038/ nclimate2067.

Turner II, B.L., W.C. Clark, R.W. Kates, J.F. Richards, J.T. Mathews, and W.B. Meyer, eds. 1990. The Earth as Transformed by Human Action: Global and Regional Changes in the Biosphere over the Past 300 years. Cambridge: Cambridge University Press.

Turner II, B.L., K.J. Esler, P. Bridgewater, J. Tewksbury, N. Sitas, B. Abrahams, F.S. Chapin III et al. 2016. 'Socio-environmental Systems (SES) research: What Have We Learned and How Can We Use this Information in Future Research Programs.' Current Opinion in Environmental Sustainability 19: 160-168. doi:10.1016/j.cosust.2016.04.001.

Turner II, B.L., E.F. Lambin, and A. Reenberg. 2007. 'The Emergence of Land Change Science for Global Environmental Change and Sustainability.' Proceedings of the National Academy of Sciences 104(52): 20666-20671. doi:10.1073/pnas.0704119104.

Turnhout, E., T. Metze, C. Wyborn, N. Klenk, and E. Louder. 2020. 'The Politics of Co-production: Participation, Power, and Transformation.' Current Opinion in Environmental Sustainability 42: 15-21. doi:10.1016/j.cosust.2019.11.009.

Van der Leeuw, S.E. 2019. Social Sustainability Past and Present: Undoing Unintended Consequences for the Earth's Survival. Cambridge: Cambridge University Press.

Villamayor-Tomas, S., C. Oberlack, G. Epstein, S. Partelow, M. Roggero, E. Kellner, M. Tschopp, and M. Cox. 2020. 'Using Case Study Data to Understand SES Interactions: A Model-centered Meta-analysis of SES Framework Applications.' Current Opinion in Environmental Sustainability 44: 48-57. doi:10.1016/j.cosust.2020.05.002.

Walker, B.H., and D. Salt, eds. 2006. Resilience Thinking. Washington DC, USA: Island Press.

Wheeler, H.C., and M. Root-Bernstein. 2020. 'Informing Decision-making with Indigenous and Local Knowledge and Science.' Journal of Applied Ecology 57: 1634-1643. doi:10.1111/1365-2664.13734.

Wheeler, T., and J. von Braun. 2013. 'Climate Change Impacts on Global Food Security.' Science 341(6145): 508-513. doi:10.1126/science.1239402.

Wilting, H.C., A.M. Schipper, M. Bakkenes, J.R. Meijer, and M.A.J. Huijbregts. 2017. 'Quantifying Biodiversity Losses Due to Human Consumption: A Global-scale Footprint Analysis.' Environmental Science and Technology 51(6): 3298-3306. doi:10.1021/acs.est.6b05296.

Zimmerer, K.S., E.F.B. Lambin, and S.J. Vanek. 2018. 'Smallholder Telecoupling and Potential Sustainability.' Ecology and Society 23(1) 30. doi:10.5751/ES-09935-230130. 